\title{
Performance of Tuberose Varieties for Flowering and Flower Yield Parameters under Indo-gangetic Plains of Eastern Uttar Pradesh, India
}

\author{
Ashish Singh*, Anil K. Singh, Anjana Sisodia and Minakshi Padhi \\ Department of Horticulture, Institute of Agricultural Sciences \\ Banaras Hindu University, Varanasi, U.P., India \\ *Corresponding author
}

\section{Keywords}

Tuberose, Variety, Flowering, Yield

Article Info

Accepted:

08 July 2018

Available Online:

10 August 2018

\section{A B S T R A C T}

An investigation on evaluation of tuberose (Polianthes tuberosa L.) was conducted during2017-2018 at Horticulture Research Farm, Department of Horticulture, Banaras Hindu University, Varanasi. In this experiment 14 tuberose varieties were evaluated. The experiment was laid out in Randomized Block Design with three replications. The results of experiment was revealed that the earliest spike emergence was recorded in variety Pune Local Single. The variety Pune Local Single was reported earliest flowering whereas, late flowering was recorded in ACC NO-9. Variety Arka Nirantara was recorded maximum length of spike while minimum length of spike was recorded in variety ACC NO7.Cultivar ACC NO-9 was recorded maximum rachis length and minimum rachis length was recorded in cultivar Mexican Single. Cultivar Phule Rajani was recorded maximum number of florets per spike and minimum number of florets per spike was recorded in cultivar Mexican Single. Maximum length of floret was reported in variety Prajwaland minimum length of floret was recorded in variety ACC NO-7.Maximum diameter of floret was recorded in variety Prajwal. Whereas, the minimum diameter of floret was recorded in variety Mexican Single. Minimum inter nodal length was recorded in variety ACC NO-7 and maximum inter nodal length was recorded in variety Calcutta Double. Variety Calcutta Single was recorded maximum duration of flowering while minimum duration of flowering was found in variety ACC NO-7. Cultivar Prajwal was recorded maximum number of spikes per plant while cv. ACC NO-7 was reported minimum number of spikes per plant.

\section{Introduction}

The flower of tuberose is liked for its prettiness, elegance and fragrance. Among the ornamental bulbous plant tuberose occupies important place. Tuberose was spread from Mexico to the different countries during $16^{\text {th }}$ century (Singh and Sisodia, 2017). Tuberose is commercially grown for cut flower, loose flower as well as perfume industries. The flowers of tuberose used for floral ornamental, decoration, bouquets and in garlands. Tuberose is also preferred for table decoration in bowl and vase because its spike remains fresh for long time (Singh, 2006). Tuberose is hardy, perennial bulbous plant with fibrous 
root and perpetuating itself through bulblets. The leaves are long, narrow and grass like foliage with light green colour. The flowers are waxy, white coloured and funnel shaped. It has six stamen and three locular ovary and fruits are capsule. Tuberose occupied important position in local as well as global markets. Evaluation of tuberose varieties for a region to get commercial yield. The aim of the experiment is to find the suitable cultivars to this climatic condition and to improve the economic condition of farmer.

\section{Materials and Methods}

The present investigation on evaluation of 14 tuberose varieties viz., Shringar, Calcutta Double, Vaibhav, GKTC-4, Sikkim Selection, Prajwal, Hyderabad Single, PhuleRajani, ACC NO-9, Pune Local Single, ArkaNirantara, ACC NO-7, Calcutta Single and Mexican Single was laid out at Horticulture Research Farm, Department of Horticulture, Banaras Hindu University, Varanasi during 2017 to 2018. The bulbs were planted at $30 \times 20 \mathrm{~cm}$ apart at $8 \mathrm{~cm}$ depth. The uniform intercultural operations were adopted for all varieties and replications throughout the experiment. The experiment was carried out in Randomized Block Design with three replications. The observations were recorded on different flowering parameters viz., days to spike emergence, days to flowering, length of spike, rachis length, number of florets per spike, length of floret, diameter of floret, inter nodal length, duration of flowering and number of spikes per plant. The observations were taken from five selected plants from each replication.

\section{Results and Discussion}

Varieties of tuberose responded significantly for various flowering parameters (Table 1 and 2). Cultivar Pune Local Single was reported earliest spike emergence which was statistically at par with caves. Sikkim
Selection (43.93 days), Calcutta Single (51.60 days), Calcutta Double (51.60 days), Vaibhav (52.40 days) and Mexican Single (53.47 days). Late spike emergence was recorded in germplasm ACC NO-9 (80.93 days).

The varietal difference in spike emergence was also reported by Chaturvedi et al., (2014) and Ramachandru and Thangam (2009). Cultivar Pune Local Single was recorded earliest flowering (56.47 days) which was statistically at par with cvs. Sikkim Selection (57.07 days), Mexican Single (67.53 days) and Calcutta Single (68.33 days). Late flowering was recorded in germplasm ACC NO-9 (94.20 days). Difference in days to flowering was also reported by Singh et al., (2013) and Krishnamoorthy (2014). Cultivar Arka Nirantara was recorded maximum length of spike $(98.48 \mathrm{~cm})$ and significant with cvs. ACC NO-9 and Prajwal. Whereas, the minimum length of spike was recorded with ACC NO-7.

The variation in length of spike as affected by different varieties was also noticed by Patil et al., (2009) and Chaturvedi et al., (2014). Germplasm ACC NO-9 was reported maximum rachis length $(34.01 \mathrm{~cm})$ which was statistically at par with cv. Vaibhav (32.75 $\mathrm{cm})$ and minimum rachis length was recorded in variety Mexican Single $(10.59 \mathrm{~cm})$. The varietal difference in rachis length was also reported by Prakash et al., (2015) and Rao and Sushma (2015). Maximum number of florets per spike (44.87) was recorded in cv. Phule Rajani which was statistically at par with Pune Local Single (41.67) and GKTC-4 (40.13). Variation in various flowering parameters in different varieties was due to genetic make of germplasm. The minimum number of florets per spike was found in cultivar Mexican Single (20.07). The variation in number of florets per spike was also noticed by Ranchana et al., (2015) and Vijayalaxmi and Lakshmidevamma (2016). 
Table.1 Evaluation of tuberose varieties for flowering characters

\begin{tabular}{|l|c|c|c|c|c|}
\hline \multicolumn{1}{|c|}{ Treatment } & $\begin{array}{c}\text { Days to spike } \\
\text { emergence }\end{array}$ & $\begin{array}{c}\text { Days to } \\
\text { flowering }\end{array}$ & $\begin{array}{c}\text { Length of } \\
\text { spike }(\mathrm{cm})\end{array}$ & $\begin{array}{c}\text { Rachis length } \\
(\mathrm{cm})\end{array}$ & $\begin{array}{c}\text { No. of } \\
\text { florets/spike }\end{array}$ \\
\hline Shringar & 71.27 & 81.20 & 67.67 & 25.24 & 37.73 \\
\hline Calcutta Doubl & 51.60 & 76.20 & 78.46 & 27.74 & 27.40 \\
\hline Vaibhav & 52.40 & 78.67 & 73.89 & 32.75 & 37.73 \\
\hline GKTC-4 & 61.93 & 76.53 & 69.79 & 24.62 & 40.13 \\
\hline Sikkim Selection & 43.93 & 57.07 & 55.30 & 16.68 & 23.67 \\
\hline Prajwal & 72.40 & 85.47 & 83.87 & 24.73 & 34.13 \\
\hline Hyderabad Single & 69.20 & 80.80 & 67.61 & 25.74 & 36.07 \\
\hline PhuleRajani & 65.07 & 77.27 & 62.44 & 22.39 & 44.87 \\
\hline ACC NO-9 & 80.93 & 94.20 & 84.99 & 34.01 & 36.00 \\
\hline Pune Local Single & 41.20 & 56.47 & 63.19 & 18.92 & 41.67 \\
\hline ArkaNirantara & 60.80 & 75.15 & 98.48 & 20.51 & 22.95 \\
\hline ACC NO-7 & 70.40 & 80.53 & 41.71 & 14.13 & 36.73 \\
\hline Calcutta Single & 51.60 & 68.33 & 71.94 & 23.15 & 35.47 \\
\hline Mexican Single & 53.47 & 67.53 & 56.34 & 10.59 & 20.07 \\
\hline C.D. at 5\% & 12.61 & 12.28 & 6.21 & 5.59 & 6.25 \\
\hline
\end{tabular}

Table.2 Performance of tuberose varieties for flowering parameters

\begin{tabular}{|l|c|c|c|c|c|}
\hline \multicolumn{1}{|c|}{ Treatment } & $\begin{array}{c}\text { Length of } \\
\text { floret }(\mathrm{cm})\end{array}$ & $\begin{array}{c}\text { Diameter } \\
\text { of floret } \\
(\mathrm{cm})\end{array}$ & $\begin{array}{c}\text { Inter nodal } \\
\text { length } \\
\text { (cm) }\end{array}$ & $\begin{array}{c}\text { Duration of } \\
\text { flowering } \\
\text { (days) }\end{array}$ & $\begin{array}{c}\text { No. of } \\
\text { spikes/plant }\end{array}$ \\
\hline Shringar & 4.50 & 3.65 & 3.52 & 13.53 & 2.20 \\
\hline Calcutta Double & 4.39 & 4.40 & 5.31 & 15.80 & 2.43 \\
\hline Vaibhav & 5.52 & 4.22 & 4.96 & 13.93 & 1.93 \\
\hline GKTC-4 & 4.41 & 3.67 & 4.62 & 13.07 & 1.67 \\
\hline Sikkim Selection & 5.04 & 3.28 & 3.71 & 13.67 & 2.20 \\
\hline Prajwal & 5.65 & 4.64 & 4.21 & 15.60 & 2.60 \\
\hline Hyderabad Single & 4.94 & 4.10 & 4.76 & 12.93 & 1.67 \\
\hline PhuleRajani & 5.41 & 4.35 & 3.93 & 12.73 & 1.47 \\
\hline ACC NO-9 & 4.74 & 3.88 & 4.52 & 12.20 & 1.40 \\
\hline Pune Local Single & 4.70 & 3.55 & 3.80 & 12.60 & 1.53 \\
\hline ArkaNirantara & 4.75 & 3.67 & 3.17 & 12.05 & 1.75 \\
\hline ACC NO-7 & 3.60 & 3.31 & 2.39 & 10.00 & 1.20 \\
\hline Calcutta Single & 4.71 & 3.46 & 4.41 & 18.40 & 1.60 \\
\hline Mexican Single & 4.58 & 2.92 & 4.15 & 16.47 & 1.87 \\
\hline C.D. at 5\% & 0.31 & 0.22 & 0.63 & 2.36 & 0.15 \\
\hline
\end{tabular}

Maximum length of floret was exhibited by the cv.Prajwal $(5.65 \mathrm{~cm})$ which was statistically at par with $\mathrm{cv}$. Vaibhav $(5.52 \mathrm{~cm})$ and minimum length of floret was found in germplasm ACC NO-7. Similar results were also investigated by Dimri et al., (2017) and Singh et al., (2013). 
Maximum diameter of floret was shown in variety Prajwal $(4.64 \mathrm{~cm})$ followed by cvs. Calcutta Double $(4.40 \mathrm{~cm})$, PhuleRajani (4.35 $\mathrm{cm})$ and Vaibhav $(4.22 \mathrm{~cm})$. Whereas, the minimum diameter of floret was recorded in variety Mexican Single $(2.92 \mathrm{~cm})$. Similar result was also reported by Singh et al., (2013) and Singh and Dakho (2017). The minimum inter nodal length was recorded in cv. ACC NO-7 $(2.39 \mathrm{~cm})$ followed by Arka Nirantara $(3.17 \mathrm{~cm})$ and Shringar $(3.51 \mathrm{~cm})$. Maximum inter nodal length was recorded in variety Calcutta Double $(5.31 \mathrm{~cm})$. Cultivar Calcutta Single was recorded maximum duration of flowering (18.40 days) which was statistically at par with Mexican Single (16.47 days) while minimum duration of flowering was found in germplasm ACC NO-7 (10.00 days). The difference in duration of flowering was experimentally corroborated by Ranchana et al., (2015) and Prashanta et al., (2016). Maximum number of spikes per plant was recorded in cultivarPrajwal (2.60) which was statistically at parwithevs. Calcutta Double (2.43), Shringar (2.20) and Sikkim Selection (2.20) and minimum number of spikes per plant was found with germplasm ACC NO-7 (1.20). Results are in line with those obtained by Ranchana et al., (2015) and Susila (2013).

\section{References}

Chaturvedi, A., Mishra, T.S., Kumar, N. and Singh, S.S. 2014. Screening of different cultivars of tuberose (Polianthes tuberosa L.) under agro-climatic conditions of Allahabad. Progressive Horticulture, 46(1): 146-148.

Dimri, S., Punetha, P., Bohra, M. and Tanuja. 2017. Screening of suitable germplasm of tuberose (Polianthes tuberosaL.) for mid hill conditions of Garhwal Himalayas. International Journal of Agricultural Science and Research, 7(2): 499-506.

Krishnamoorthy, V. 2014. Assessment of tuberose (Polianthes tuberosa) varieties for growth and yield characters. Asian Journal of Horticulture, 9(2): 515-517.

Patil, V.S., Munikrishnappa, P.M. and Shantappa,
T. 2009. Performance of growth and yield of different genotypes of tuberose under transitional tract of north Karnataka. Journal of Ecobiology, 24(4): 327-333.

Prakash, S., Arya, J.K., Singh, R.K. and Singh, K.P. 2015. Varietal performance of tuberose in Muzaffarnagar under Western plain zone condition. Asian Journal of Horticulture, 10(1): 149-152.

Prashanta, M., Parul, P. and Rana, D.K. 2016. Evaluation of tuberose genotypes for vegetative, floral and bulb yielding attributes under the valley conditions of Garhwal Himalayas. International Journal of Agriculture Sciences, 8(62):3522-3524.

Ramachandrudu, K. and Thangam, M. 2009. Performance of tuberose (Polianthes tuberosa L.) cultivars in Goa. Journal of Horticultural Science, 4(1): 76-77.

Ranchana, P., Kannan, M. and Jawaharlal, M. 2015. Evaluation of tuberose (Polianthe stuberosa) genotypes (double) for yield and genetic variability. Trends in Biosciences, 8(7): 1766-1769.

Rao, K.D. and Sushma, K. 2015. Evaluation of certain tuberose (Polianthes tuberosa L.) double genotypes for assessing the yield and quality traits under agro climatic conditions of Telangana. The Journal of Research PJTSAU, 43(1-2): 51-56.

Singh, A.K. 2006. Flower Crops Cultivation and Management, New India Publishing Agency, New Delhi. pp. 357.

Singh, A.K. and Dakho, J. 2017. Evaluation on performance and superiority of tuberose (Polianthes tuberosa L.) cultivars for growth and flowering under North Indian plain. Environment and Ecology, 35(1A): 341-345.

Singh, A.K. and Sisodia, A. 2017. Textbook of Floriculture and Landscaping, New India Publishing Agency, New Delhi. pp. 415.

Singh, A.K., Kumar, A. and Sisodia, A. 2013. Growth, flowering and bulb yield in tuberose as influenced by cultivars. Environment and Ecology, 31(4A): 1823-1825.

Singh, A.K., Sisodia, A., Sisodia, V. and Ray, P. 2017. Performance of Indian and exotic 
varieties of gladiolus under eastern UP conditions. Journal Ornamental Horticulture, 20(3\&4): 153-157.

Susila, T. 2013. Performance of tuberose cultivars under north coastal Andhra Pradesh, India. Agricultural Science Digest, 33(2):
161-162.

Vijayalaxmi, G.P. and Lakshmidevamma, T.N. 2016. Evaluation of tuberose (Polianthes tuberosa) varieties for quality traits. Advances in Life Sciences, 5(12): 5370-5371.

\section{How to cite this article:}

Ashish Singh, Anil K. Singh, Anjana Sisodia and Minakshi Padhi. 2018. Performance of Tuberose Varieties for Flowering and Flower Yield Parameters under Indo-gangetic Plains of Eastern Uttar Pradesh, India. Int.J.Curr.Microbiol.App.Sci. 7(08): 1129-1133.

doi: https://doi.org/10.20546/ijcmas.2018.708.128 